\title{
OPTIMIZATION OF CULTURE MEDIUM FOR ENHANCED PROTEASE BIOSYNTHESIS in Streptomyces globisporus
}

\author{
R.K. Blieva ${ }^{1}$, K.G. Mustafin ${ }^{1}$, N.N. Akhmetsadykov ${ }^{1}$, Zh.B. \\ Suleimenova $^{1, \bowtie}$, A.K. Kalieva ${ }^{2}$, Zh.B. Narmuratova ${ }^{3}$, Zh.K. Saduyeva ${ }^{1}$, \\ A.S. Zhakipbekova ${ }^{1}$ and I.E. Tapenbayeva ${ }^{1}$ \\ ${ }^{1}$ Department of Biochemistry, Research and Production Enterprise Antigen Co. Ltd., 4 \\ Azerbaev Str., Karasay Area, Abay vill., 040509 Almaty, Kazakhstan \\ ${ }^{2}$ Department of Biology, K. Zhubanov Aktobe regional State University, 34 A. Moldagulova \\ Avenue, 030000 Aktobe, Kazahstan \\ ${ }^{3}$ Al-Farabi Kazak National University, 71 al-Farabi Avenue, 050040 Almaty, Kazakhstan \\ ${ }^{\square}$ Corresponding Author: raubil@mail.ru
}

\begin{abstract}
In present study screening of strain strongly producing protease enzyme was conducted. Streptomyces globisporus $1 / 68$ was found to possess maximum protein degrading capacity. The effect of carbon sources, inorganic and organic nitrogen sources on protease production by Streptomyces globisporus 1/68 was evaluated. The optimal carbon and nitrogen sources in the nutrient medium were selected. Maximal protease production was shown in medium with galactose as a carbon source $(1.2 \mathrm{U} / \mathrm{ml})$. Among inorganic nitrogen sources tested ammonium dihydrogen phosphate $\left(\mathrm{NH}_{4} \mathrm{H}_{2} \mathrm{PO}_{4}\right)$ supported moderate growth and protease production in Streptomyces globisporus $1 / 68$ with enzymatic activity of $5.8 \mathrm{U} / \mathrm{ml}$. The addition of organic nitrogen sources did not affect the protease biosynthesis in tested culture. Besides, amino acids supplemented in medium with selected nitrogen inorganic source had no significant effect on protease biosynthesis in by Streptomyces globisporus 1/68.
\end{abstract}

Keywords: Microbial Enzymes, Growth Conditions, Protease, Carbon Sources, Nitrogen Sources, Streptomyces globisporus.

RASĀYAN J. Chem., Vol. 14, No.1, 2021

\section{INTRODUCTION}

Proteases are industrial enzymes that catalyze the hydrolysis of peptide bonds in proteins and have applications in detergent, food, feed, pharmaceutical, leather industries and bioremediation process ${ }^{1-5}$. These enzymes account around $50-60 \%$ of the total worldwide enzyme market and can be obtained from plants, animals, and microorganisms ${ }^{6-10}$. However most commercially important proteases are obtained from microorganisms since microbial enzymes can usually be obtained in large quantities, on a regular basis and with the same quality. Besides, microbial enzymes are generally more stable, their production processes are faster and nutritional needs are relatively simple. In addition, microbes can be genetically manipulated to obtain the desired characteristics, to increase activity and productivity ${ }^{11-13}$. The producers of proteases were found among Aspergillus niger, A.terricola, A.oryzae, A.awamori, Bacillus cereus, Bacillus subtilis, Streptomyces griseus, Streptomyces chromogenes Actinomyces fradiae etc. ${ }^{14-19}$ Recently, micromycetes and actinomycetes have been widely used because of the ease of their cultivation and high productivity.

Proteases produced by microorganisms are constitutive or inducible in nature, and their production depends on culture conditions. The ability to control the enzymes production by regulation of their biosynthesis allows not only to increase the yield of enzymes, but also to obtain enzyme preparations with certain properties. Various factors affect the production of the protease enzymes, such as nitrogen and carbon sources, the inoculum concentration, fermentation period, $\mathrm{pH}$, temperature, etc. ${ }^{20-27}$ About $30 \%$ of the industrial enzymes cost depends on the cost of the nutrient medium. In this regards, the main objective of fundamental research for the industrial enzymes application is to reduce their production costs by optimization of fermentation medium. Present investigation focused on screening of microbial strain strongly producing protease enzyme and optimization of media components (carbon and nitrogen sources) for enhanced protease production by obtained strain. 


\section{Material and Methods}

\section{EXPERIMENITAL}

The pure strains of Aspergillus and Penicillium fungi as well as Streptomyces globisporus 1/68 (own collection) were screened for extra cellular protease production. Primary selection was carried out on Chapek-Doks medium containing 1\% sodium casein, peptone and wheat bran as specific substrates. The clearance zone and colony diameter were measured after 5 days of incubation time at $30^{\circ} \mathrm{C}$. The ability of microorganisms to use specific substrate as the sole source of protein was studied. Only positive and better zone formed strain was taken for further study.

The effect of various carbon and nitrogen sources on protease production was investigated. Basal medium of the following composition was used: $\mathrm{NaNo}_{3}-0,15 \%$ (on $\left.\mathrm{N}\right) ; \mathrm{KCl}-0,05 \% ; \mathrm{MgSO}_{4}-0,05$ $\% ; \mathrm{KH}_{2} \mathrm{PO}_{4}-0,1 \% ; \mathrm{FeSO}_{4}-0,001 \%$; mannitol $-2 \%$.

As inorganic nitrogen sources $\left(\mathrm{NH}_{4}\right)_{2} \mathrm{SO}_{4}, \mathrm{NH}_{4} \mathrm{Cl}, \mathrm{NH}_{4} \mathrm{NO}_{3}, \mathrm{NaNO}_{3}, \mathrm{NH}_{4} \mathrm{H}_{2} \mathrm{PO}_{4},\left(\mathrm{NH}_{4}\right)_{3} \mathrm{PO}_{4}$, $\left(\mathrm{NH}_{4}\right) \mathrm{MoO}_{4}$ at a concentration of $0.5 \%$ by volume of the medium were used.

As organic nitrogen sources Peptone, Casein, Wheat bran, Wheat flour, Soy flour, Whey $2 \%$, Whey $5 \%$ at a concentration of $1.0 \%$ by volume of the medium were used.

As carbon sources Galactose, Arabinose, Fructose, Starch, Maltose, Mannitol, Sucrose, Glucose, Mannose, Glycerin, Lactose and Sorbitol were used at a concentration of $1.5 \%$ by volume of the medium.

A $2 \%$ microbial suspension was sterilized in all flasks and placed on a shaker at $220-240 \mathrm{rpm}$ for 72 hours. After this fermentation time, the protease activity of the culture fluid of all variants was assayed according to Anson's method ${ }^{28}$. One unit of the protease activity was expressed in micromoles of tyrosine formed in $1 \mathrm{ml}$ of culture fluid for $1 \mathrm{~min}$.

Microbial biomass was determined by gravimetric method. Mycelium was separated from the medium by filtration through Whatman filter paper, washed, dried to constant weight at $86^{\circ} \mathrm{C}$. All the analyses were performed in triplicate, and the results were expressed as mean \pm standard deviation using Excel 2010.

\section{RESULTS AND DISCUSSION \\ Screening of Microscopic Strain Strongly Producing Protease Enzyme}

To assess the potential for protease production Aspergillus and Penicillium fungi as well as Streptomyces globisporus 1/68, known as potential protease producers were analyzed for protease activity. Microbial cultures were inoculated in agar medium containing protein substrates. The zone of clearing around the microbial growth was indicator of protease production (Fig.-1).

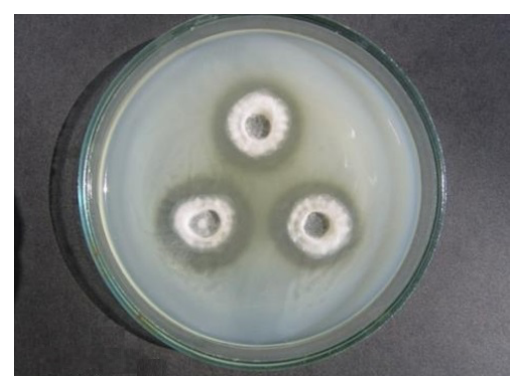

Fig.-1: Zones of Substrate Hydrolysis

The clear zone formation concerns the ability of colonies with confirmed protein hydrolysis. During the initial screening of pure strains of Aspergillus and Penicillium fungi as well as Streptomyces globisporus 1/68 for synthesis of protease enzyme it was found that not all strains grew on the medium containing casein, peptone and wheat bran as specific substrates (Table-1).

Table-1: Extracellular Protease Enzyme Production on Various Protein Substrates

\begin{tabular}{l|c|c|c}
\hline \multirow{2}{*}{ Strain } & \multicolumn{3}{|c}{ Zones of Substrate Hydrolysis (mm) } \\
\cline { 2 - 4 } & Casein & Peptone & Wheat Bran \\
\hline Streptomyces globisporus 1/68 & 25.6 & $22.5 \pm 1.2$ & $21.4 \pm 1.2$ \\
\hline Aspergillus awamori 16 & $19.6 \pm 1.2$ & $17.5 \pm 1.6$ & $15.4 \pm 0,9$ \\
\hline Aspergillus awamori 22 & $16.9 \pm 1.3$ & $15.4 \pm 1.3$ & $14.3 \pm 1.8$ \\
\hline
\end{tabular}


RASĀYAN $J$. Chem.

Vol. 14 | No. 1 |270-275| January - March | 2021

\begin{tabular}{l|c|c|c}
\hline Aspergillus awamori 21/95 & $15.5 \pm 1.4$ & $13.4 \pm 1.6$ & $11.3 \pm 1.7$ \\
\hline Aspergillus awamori 21/96 & $16.7 \pm 1.3$ & $15.6 \pm 0.8$ & $12.1 \pm 1.5$ \\
\hline Aspergillus awamori 426 & $11.3 \pm 1.2$ & $13.2 \pm 1.2$ & $13.3 \pm 1.1$ \\
\hline Aspergillus foetidus 26 & 0 & 0 & 0 \\
\hline Aspergillus oryzae 3-9-15 & 0 & 0 & 0 \\
\hline Aspergillus oryzae 476 & 0 & 0 & 0 \\
\hline Aspergillus niger $\Pi$ & 0 & 0 & 0 \\
\hline Penicillum chryzogenum 241 & 0 & 0 & 0 \\
\hline Penicillum chryzogenum 245 & 0 & 0 & 0 \\
\hline
\end{tabular}

Among the studied strains, Streptomyces globisporus 1/68 was found to possess maximum protein degrading capacity which was identified by the presence of clearance zone in protease screening medium containing sodium casein, peptone and wheat bran as substrate. Zones of substrate hydrolysis by Streptomyces globisporus $1 / 68$ on the 5 th day were $25.6 \mathrm{~mm}$. In other variants, the diameter of clearance zones varied from $11.3 \mathrm{~mm}$ to $16.9 \mathrm{~mm}$. Thus, Streptomyces globisporus $1 / 68$ was selected for further investigations.

\section{Effect of Various Inorganic and Organic Nitrogen Sources on Protease Production by Streptomyces globisporus $1 / 68$}

The composition of the growth medium is very important aspect in the development of fermentation processes. Nitrogen is one of the essential elements, which play an important role in physiological control, regulation of metabolisms and enzyme synthesis. In present work the effect of different inorganic and organic nitrogen sources on protease production by $S$. globisporus 1/68 was investigated. The effect of nitrogen sources on protease production is presented in Tables- 2 and 3.

Table-2: Effect of Inorganic Nitrogen Sources on Protease Production by Streptomyces globisporus 1/68

\begin{tabular}{c|c|c|c}
\hline Nitrogen Source & $\mathrm{pH}$ & Biomass, g/100 ml & Protease Activity, U/ml \\
\hline$\left(\mathrm{NH}_{4}\right)_{2} \mathrm{SO}_{4}$ & 4.0 & $0.143 \pm 0.08$ & $1.4 \pm 0.5$ \\
\hline $\mathrm{NH}_{4} \mathrm{Cl}$ & 4.0 & $0.158 \pm 0.10$ & $2.1 \pm 0.38$ \\
\hline $\mathrm{NH}_{4} \mathrm{NO}_{3}$ & 6.0 & $0.134 \pm 0.11$ & $3.2 \pm 0.44$ \\
\hline $\mathrm{NaNO}_{3}$ & 6.5 & $0.243 \pm 0.08$ & $0.9 \pm 0.36$ \\
\hline $\mathrm{NH}_{4} \mathrm{H}_{2} \mathrm{PO}_{4}$ & 6.4 & $0.103 \pm 0.09$ & $5.8 \pm 0.49$ \\
\hline$\left(\mathrm{NH}_{4}\right)_{3} \mathrm{PO}_{4}$ & 5.9 & $0.14 \pm 0.10$ & 0 \\
\hline$\left(\mathrm{NH}_{4}\right)_{\mathrm{MoO}_{4}}$ & 6.6 & $0.139 \pm 0.08$ & $2.7 \pm 0.61$ \\
\hline
\end{tabular}

Table-3: Effect of Organic Nitrogen Sources on Protease Production by Streptomyces globisporus 1/68

\begin{tabular}{c|c|c|c}
\hline Nitrogen Source & $\mathrm{pH}$ & Biomass, g/100 ml & Protease Activity, U/ml \\
\hline Peptone & 5.7 & - & $1.6 \pm 0.33$ \\
\hline Casein & 5.0 & - & $0.7 \pm 0.45$ \\
\hline Wheat bran & 6.3 & - & $1.1 \pm 0.4$ \\
\hline Wheat flour & 5.3 & $0.135 \pm 0.08$ & $1.5 \pm 0.29$ \\
\hline Soy flour & 4.7 & $0.186 \pm 0.07$ & $1.9 \pm 1.02$ \\
\hline Whey 2\% & 5.8 & $0.364 \pm 0.34$ & $0.9 \pm 0.65$ \\
\hline Whey 5\% & 6.0 & $0.112 \pm 0.09$ & $1.6 \pm 0.77$ \\
\hline
\end{tabular}

The experiments showed that a significant amount of protease enzyme was formed on inorganic nitrogen sources in comparison with organic sources. Among the inorganic nitrogen sources, $\mathrm{NH}_{4} \mathrm{H}_{2} \mathrm{PO}_{4}$ supported moderate growth and protease production in Streptomyces globisporus 1/68 with enzymatic activity of $5.8 \mathrm{U} / \mathrm{ml}$. All other nitrogen and organic sources used had less effect on protease production. This indicates that $\mathrm{NH}_{4} \mathrm{H}_{2} \mathrm{PO}_{4}$ is the most efficient source for protease production by Streptomyces globisporus 1/68.

As Streptomyces globisporus 1/68 is actinomycete it was supposed that amino acids can affect the protease production in Streptomyces globisporus 1/68. Therefore, the effect of amino acid supplemented in medium with an optimal nitrogen inorganic source $\left(\mathrm{NH}_{4} \mathrm{H}_{2} \mathrm{PO}_{4}\right)$ was investigated. As can be seen from data presented in Table-4 all amino acids supplemented in medium with nitrogen 
inorganic source ammonium dihydrogen phosphate had no effect on protease production in Streptomyces globisporus 1/68.

Table-4: Effect of Amino Acids on Protease Production by Streptomyces globisporus 1/68

\begin{tabular}{c|c|c|c|c}
\hline Nitrogen Source & Amino Acid & $\mathrm{pH}$ & Biomass, g/100 ml & Protease Activity, U/ml \\
\hline $\mathrm{NH}_{4} \mathrm{H}_{2} \mathrm{PO}_{4}$ & - & 6.4 & $0.103 \pm 0.04$ & $5.8 \pm 0.34$ \\
\hline $\mathrm{NH}_{4} \mathrm{H}_{2} \mathrm{PO}_{4}$ & $\begin{array}{c}\text { Hydrochloric } \\
\text { arginine }\end{array}$ & 6.5 & $0.146 \pm 0.09$ & $1.1 \pm 0.45$ \\
\hline $\mathrm{NH}_{4} \mathrm{H}_{2} \mathrm{PO}_{4}$ & $\begin{array}{c}\text { Arginine } \\
\text { hydrochloride }\end{array}$ & 5.4 & $0.102 \pm 0.1$ & $1.2 \pm 0.62$ \\
\hline $\mathrm{NH}_{4} \mathrm{H}_{2} \mathrm{PO}_{4}$ & Valine & 5.6 & $1.132 \pm 0.23$ & 0 \\
\hline $\mathrm{NH}_{4} \mathrm{H}_{2} \mathrm{PO}_{4}$ & Histidine & 6.0 & $0.084 \pm 0.01$ & $2.0 \pm 0.32$ \\
\hline $\mathrm{NH}_{4} \mathrm{H}_{2} \mathrm{PO}_{4}$ & Glutamine & 5.4 & $0.05 \pm 0.02$ & $2.8 \pm 0.19$ \\
\hline $\mathrm{NH}_{4} \mathrm{H}_{2} \mathrm{PO}_{4}$ & Leucine & 5.1 & $0.253 \pm 0.1$ & $0.9 \pm 0.21$ \\
\hline $\mathrm{NH}_{4} \mathrm{H}_{2} \mathrm{PO}_{4}$ & Hydrochloric acid & 5.6 & $0.032 \pm 0.01$ & $1.1 \pm 0.18$ \\
\hline $\mathrm{NH}_{4} \mathrm{H}_{2} \mathrm{PO}_{4}$ & lysine & & $0.061 \pm 0.02$ & $2.7 \pm 0.52$ \\
\hline $\mathrm{NH}_{4} \mathrm{H}_{2} \mathrm{PO}_{4}$ & Methionine & 6.0 & $0.082 \pm 0.03$ & $1.2 \pm 0.44$ \\
\hline $\mathrm{NH}_{4} \mathrm{H}_{2} \mathrm{PO}_{4}$ & Ornithine & 5.5 & $0.093 \pm 0.01$ & $1.1 \pm 0.36$ \\
\hline $\mathrm{NH}_{4} \mathrm{H}_{2} \mathrm{PO}_{4}$ & Threonine & 5.7 & $0.156 \pm 0.02$ & 0 \\
\hline $\mathrm{NH}_{4} \mathrm{H}_{2} \mathrm{PO}_{4}$ & Tryptophan & 5.4 & $0.160 \pm 0.07$ & $1.9 \pm 0.28$ \\
\hline $\mathrm{NH}_{4} \mathrm{H}_{2} \mathrm{PO}_{4}$ & Serine & 4.5 & $0.105 \pm 0.07$ & $1.1 \pm 0.48$ \\
\hline $\mathrm{NH}_{4} \mathrm{H}_{2} \mathrm{PO}_{4}$ & $\beta-$ phenyl- $\alpha-$ alanine & 5.7 & $0.099 \pm 0.04$ & \\
\hline
\end{tabular}

There are various ways of regulation of enzyme biosynthesis. In some cases much depends on whether the enzyme is constitutive or inducible. An inducible enzyme is an enzyme that is produced under conditions where it has no adaptive properties (for example, in the presence of an inducer/substrate in a nutrient medium), in contrast to a constitutive enzyme, which is produced all the time ${ }^{29}$.

Therefore, next step of study was to elucidate the constitutive or inducible nature of protease enzyme produced by Streptomyces globisporus 1/68. To identify the induced or constitutive nature of protease biosynthesis, an experiment was conducted with simultaneous addition of protein substrates in a production medium (Table-5).

Table- 5: Effect of Protein Substrates on the Protease Biosynthesis by Streptomyces globisporus 1/68

\begin{tabular}{c|c|c|c}
\hline Variant & $\mathrm{pH}$ & Biomass, g / 100 ml & $\begin{array}{c}\text { Protease Activity, } \\
\mathrm{U} / \mathrm{ml}\end{array}$ \\
\hline $\mathrm{NH}_{4} \mathrm{H}_{2} \mathrm{PO}_{4}$ & 6.4 & $0.103 \pm 0.14$ & 5.8 \\
\hline $\mathrm{NH}_{4} \mathrm{H}_{2} \mathrm{PO}_{4}+$ Peptone & 5.0 & $0.111 \pm 0.31$ & 5.3 \\
\hline $\mathrm{NH}_{4} \mathrm{H}_{2} \mathrm{PO}_{4}+$ Casein & 5.3 & $0.238 \pm 0.45$ & 0.5 \\
\hline $\mathrm{NH}_{4} \mathrm{H}_{2} \mathrm{PO}_{4}+$ Wheat bran & 5.4 & $0.304 \pm 0.23$ & 1.1 \\
\hline $\mathrm{NH}_{4} \mathrm{H}_{2} \mathrm{PO}_{4}+$ Milk whey 5\% & 6.0 & $0.156 \pm 0.09$ & 3.0 \\
\hline $\mathrm{NH}_{4} \mathrm{H}_{2} \mathrm{PO}_{4}+$ Soy flour & 5.2 & $0.344 \pm 0.46$ & 2.6 \\
\hline $\mathrm{NH}_{4} \mathrm{H}_{2} \mathrm{PO}_{4}+$ Wheat flour & 5.5 & $0.121 \pm 0.12$ & 2.5 \\
\hline $\mathrm{NH}_{4} \mathrm{H}_{2} \mathrm{PO}_{4}+$ Methionine & 4.6 & $0.323 \pm 0.31$ & 1.6 \\
\hline
\end{tabular}

According to our results obtained, protease biosythesis was not stimulated by the presence of protein substrates in the culture medium. This indicates that the production of the protease by Streptomyces globisporus $1 / 68$ is not inducible.

\section{Effect of Various Carbon Sources on Protease Production by Streptomyces globisporus 1/68}

Carbohydrates are one of the important factors in fungal growth. Effect of various carbon sources on protease production in Streptomyces globisporus 1/68 is shown in Table-6. The protease activity ranged from $0.62 \mathrm{U} / \mathrm{ml}$ to $1.2 \mathrm{U} / \mathrm{ml}$.

According to the obtained experimental data, all carbon sources can be divided into three groups. Monosaccharides and starch are the most digestible carbon sources, giving biomass accumulation from 0.7 to $1.1 \mathrm{~g} / 100 \mathrm{ml}$ and protease activity from 0.75 to $1.2 \mathrm{U} / \mathrm{ml}$. The second group of carbon 
sources includes sucrose, glucose, mannose, and glycerol, which gave biomass accumulation from 0.475 to $0.6 \mathrm{~g} / 100 \mathrm{ml}$. The biosynthesis of protease enzyme by Streptomyces globisporus 1/68 was maximal when glucose was used as a carbon source $(1.0 \mathrm{U} / \mathrm{ml})$. The third group of carbohydrates includes sorbitol and lactose, which are poorly digestible carbohydrates. These carbohydrates provided a weak biomass accumulation - from 0.15 to $0.295 \mathrm{~g} / 100 \mathrm{ml}$.

Thus, Streptomyces globisporus 1/68 assimilated mono-, di-, polysaccharides. Among them, galactose, glucose, maltose and starch provided relatively good growth and enzyme production, up to 1.1-1.2 U/ml.

Table-6: Effect of Organic Nitrogen Sources on Protease Production by Streptomyces globisporus 1/68

\begin{tabular}{c|c|c|c}
\hline Carbon Source & $\mathrm{pH}$ & Biomass, $\mathrm{g} / 100 \mathrm{ml}$ & Protease Activity, U/ml \\
\hline Galactose & 5.5 & $1.1 \pm 0.4$ & $1.2 \pm 0.92$ \\
\hline Arabinose & 5.5 & $0.9 \pm 0.12$ & $0.75 \pm 0.77$ \\
\hline Fructose & 5.6 & $0.89 \pm 0.32$ & $0.82 \pm 0.58$ \\
\hline Starch & 5.8 & $0.8 \pm 0.23$ & $1.1 \pm 0.45$ \\
\hline Maltose & 6.0 & $0.7 \pm 0.11$ & $1.1 \pm 0.65$ \\
\hline Mannitol & 6.5 & $0.69 \pm 0.33$ & $0.67 \pm 0.7$ \\
\hline Sucrose & 5.4 & $0.61 \pm 0.42$ & $0.72 \pm 0.45$ \\
\hline Glucose & 5.0 & $0.6 \pm 0.32$ & $1.0 \pm 0.65$ \\
\hline Mannose & 5.5 & $0.55 \pm 0.06$ & $0.77 \pm 0.32$ \\
\hline Glycerol & 5.0 & $0.475 \pm 0.1$ & $0.75 \pm 0.88$ \\
\hline Lactose & 5.5 & $0.295 \pm 0.09$ & $0.62 \pm 0.74$ \\
\hline Sorbitol & 5.6 & $0.15 \pm 0.08$ & $0.7 \pm 0.61$
\end{tabular}

\section{CONCLUSION}

The composition of the medium is the most important aspect to be considered when growing microorganisms. The culture medium should include all essential nutrients that microorganism requires. The protease production has been affected by a variety of physical and chemical factors, such as the composition of the growth medium, cell growth, methods of cultivation, inoculum concentration, time of incubation, $\mathrm{pH}$, temperature, carbon, nitrogen and mineral sources, etc. Various physical and chemical factors such as composition of growth medium, concentration of inoculum, incubation time, $\mathrm{pH}$, temperature, carbon and nitrogen sources have effect on protease biosynthesis. Our results indicate that some cultivation conditions such as carbon and nitrogen sources play significant role on protease biosynthesis by Streptomyces globisporus 1/68. The results indicated that among the various carbon sources galactose, glucose, maltose, and starch are the most suitable carbon sources for maximal protease biosynthesis (1.0-1.2 U/ml). Among the various inorganic and organic nitrogen sources $\mathrm{NH}_{4} \mathrm{H}_{2} \mathrm{PO}_{4}$ supported moderate growth and protease production in Streptomyces globisporus $1 / 68$ with enzymatic activity of $5.8 \mathrm{U} / \mathrm{ml}$. Thus, nitrogen and carbon sources are very important in metabolism of microorganisms especially in the enzymes biosynthesis.

\section{ACKNOWLEDGEMENT}

This research was funded by the Science Committee of the Ministry of Education and Science of the Republic of Kazakhstan.

\section{REFERENCES}

1. Q. Li, L. Yi, P. Marek, B. L. Iverson, FEBS Letters, 587(8), 1155(2013), DOI: 10.1016/j.febslet.2012.12.019

2. Y.Yunardi, H. Meilina, U. Fathanah, R. Mahadina, A. Rinaldi and J. Jauharlina, Rasayan Journal of Chemistry, 13(3), 1537(2020), DOI:10.31788/RJC.2020.1335706

3. X. Liu and C. Kokare, 2017, Microbial Enzymes of Use in Industry, in: Biotechnology of Microbial Enzymes, pp. 267-298.

4. S. Janaki Raman, P. D. Arumairaj, R. Tikson Sebastian, J. Jerushan, D. Jebaraj Samuel Dorai and Nathaniel Joseph Thomos, Rasayan Journal of Chemistry, 11(4), 1729(2018), DOI:10.31788/RJC.2018.1143089

5. N. Barzkar, International Journal of Biological Macromolecules, 161(15), 1216(2020), DOI:10.1016/j.ijbiomac.2020.06.072

6. Pradeep Kate, Shashikant Gaikwad, Tukaram Lokhande, Abdul Shaikh, Babasaheb Sonawane, Praffula Choudhari and Madhusudan Bachute, Rasayan Journal of Chemistry, 11(4), 1441(2018), DOI: $10.31788 /$ RJC.2018.1143080 
7. E. A. Abada, 2019, Application of Microbial Enzymes in the Dairy Industry, in: Enzymes in Food Biotechnology, Academic Press, pp. 61-72, DOI:10.1016/C2016-0-04555-2

8. V. Paramita, M.E. Yulianto and I. Hartati, Rasayan Journal of Chemistry, 12(2), 484(2019), DOI: $10.31788 /$ RJC.2019.1225070

9. B. Sharma, A. K. Dangi, P. Shukla, Journal of Environmental Management, 210, 10(2018). DOI:10.1016/j.jenvman.2017.12.075

10. N. M. Saptarini, D. Rahayu and S.A.F. Kusuma, Rasayan Journal of Chemistry, 12(4), 2074(2019), DOI:10.31788/RJC.2019.1245319

11. B. Jaouadi, N. Aghajari, R. Haser, S. Bejar, Biochimie, 92(4), 360(2010), DOI:10.1016/j.biochi.2010.01.008

12. Xiang Zheng, Xin-Hui Xing, Chong Zhang, Synthetic and Systems Biotechnology, 2(2), 75(2017), DOI:10.1016/j.synbio.2017.07.001

13. C. Wu, D. Li, X. Yang, R. Wu, J. Zhang, J. Huang, H. He, Marine Biotechnology, 18(5), 610(2016), DOI:10.1007/s10126-016-9721-9

14. J. Suriya, S. Bharathiraja, P. Manivasagan, S.-K. Kim, 2016, Enzymes From Rare Actinobacterial Strains, in: Advances in Food and Nutrition Research, pp. 67-98, DOI:10.1016/bs.afnr.2016.08.002

15. K. Purushothaman, S. K. Bhat, S. A. Singh, G. K. Marathe, A. R. G. Appu Rao, International Journal of Biological Macromolecules, 139, 199(2019), DOI:10.1016/j.ijbiomac.2019.07.133

16. K. M. Sharma, R. Kumar, S. Panwar, A. Kumar, Journal of Genetic Engineering and Biotechnology, 15(1), 115(2017), DOI:10.1016/j.jgeb.2017.02.001

17. K. I. Chimbekujwo, M. I. Ja'afaru, O. M. Adeyemo, Scientific African, 8, e00398(2020), DOI: $10.1016 /$ j.sciaf.2020.e00398

18. A. Rakova, O. Alexander, Journal of Biotechnology, 305, S58(2019), DOI: $10.1016 /$ j.jbiotec.2019.05.206

19. Y. Suberu, I. Akande, T. Samuel, A. Lawal, A. Olaniran, Biocatalysis and Agricultural Biotechnology, 18, 101011(2019), DOI:10.1016/j.bcab.2019.01.049

20. R. Wang, R. C. S. Law, C. Webb, Process Biochemistry, 40(1), 217(2005), DOI: $10.1016 /$ j.procbio.2003.12.008

21. A. Thanapimmetha, A. Luadsongkram, B. Titapiwatanakun, P. Srinophakun, Industrial Crops and Products, 37(1), 5(2012), DOI:10.1016/j.indcrop.2011.11.003

22. R. Blieva, Z. Suleimenova, A. Kalieva, N. Akhmetsadykov, A. Zhakipbekova, Zh. Saduyeva, EurAsian Journal of Biosciences, EurAsian Journal of Biosciences, 14(1), 2075(2020)

23. B. Bhunia, B. Basak, P. Bhattacharya, A. Dey, Journal of Bioscience and Bioengineering, 115(1), 86(2013), DOI:10.1016/j.jbiosc.2012.08.003

24. N. Bisko, K. Mustafin, G. Al-Maali, Zh. Suleimenova, M. Lomberg, Zh. Narmuratova, O. Mykchaylova, N. Mytropolska, A. Zhakipbekova, Czech Mycology, 72(1), 1(2020), DOI: $10.33585 / \mathrm{cmy} .72101$

25. A. R.Patel, N. U. Mokashe, D. S. Chaudhari, A. G. Jadhav, U. K. Patil, Biocatalysis and Agricultural Biotechnology, 19, 101122(2019), DOI:10.1016/j.bcab.2019.101122

26. R. Blieva, Z. Suleimenova, G. Ultanbekova, N. Akmukhanova, N. Altybaeva and A. Nurmahanova, Annals of Agri Bio Research, 24(2), 273(2019)

27. J. R. Dutta, P. K. Dutta, R. Banerjee, Process Biochemistry, 39(12), 2193(2004), DOI:10.1016/j.procbio.2003.11.009

28. M.L. Anson, Journal of General Physiology, 22, 79(1938).

[RJC-6123/2020] 